\title{
ANTIBACTERIAL ACTIVITY OF GUAVA, Psidium guajava LINNAEUS, LEAF EXTRACTS ON DIARRHEA-CAUSING ENTERIC BACTERIA ISOLATED FROM SEABOB SHRIMP, Xiphopenaeus kroyeri (HELLER)
}

\author{
Flávia A. GONÇALVES(1), Manoel ANDRADE NETO(2), José N. S. BEZERRA(2), Andrew MACRAE(3), Oscarina Viana de SOUSA(4),
} Antonio A. FONTELES-FILHO(5) \& Regine H.S.F. VIEIRA(5)

\begin{abstract}
SUMMARY
Guava leaf tea of Psidium guajava Linnaeus is commonly used as a medicine against gastroenteritis and child diarrhea by those who cannot afford or do not have access to antibiotics. This study screened the antimicrobial effect of essential oils and methanol, hexane, ethyl acetate extracts from guava leaves. The extracts were tested against diarrhea-causing bacteria: Staphylococcus aureus, Salmonella spp. and Escherichia coli. Strains that were screened included isolates from seabob shrimp, Xiphopenaeus kroyeri (Heller) and laboratory-type strains. Of the bacteria tested, Staphylococcus aureus strains were most inhibited by the extracts. The methanol extract showed greatest bacterial inhibition. No statistically significant differences were observed between the tested extract concentrations and their effect. The essential oil extract showed inhibitory activity against S. aureus and Salmonella spp. The strains isolated from the shrimp showed some resistance to commercially available antibiotics. These data support the use of guava leaf-made medicines in diarrhea cases where access to commercial antibiotics is restricted. In conclusion, guava leaf extracts and essential oil are very active against $S$. aureus, thus making up important potential sources of new antimicrobial compounds.
\end{abstract}

KEYWORDS: Guava leaves; Psidium guajava Linnaeus; Methanol extract; Antibacterial activity; Essential oils; Plant remedy.

\section{INTRODUCTION}

Amongst the various forms of treatment for diarrhea, the use of traditional plant remedies is common and widespread. The World Health Organization (WHO) has catalogued more than 20,000 plant species with medicinal properties providing treatments for such complaints as pneumonia, ulcers, diarrhea, bronchitis, colds and diseases of the respiratory tract. One method, amongst the many ways in which plants are used in popular remedies, is to extract and consume essential plant oils. Essential oils are complex chemical mixtures, typically composed of more than a hundred compounds, by and large, are responsible for plant aromas. They are obtained from different parts of the plant: flowers, leaves, seeds, bark and tubers and many have medicinal properties $^{2}$.

Outbreaks of diarrhea are common in communities living in precarious conditions with poor sewerage and hygiene. A number of food types have been linked to outbreaks and act as the carriers of infectious microbes. Under such conditions, diarrhea is a common occurrence after eating contaminated fish products. Illnesses arise because the microbial causal agents, often native to the fish itself, have not been adequately controlled, or arise as a consequence of incorrect handling and or storage during industrial processing ${ }^{13}$. Illnesses causing gastroenteritis and diarrhea are primarily associated with enteric bacteria. Enteric bacteria are responsible for high mortality rates in numerous developing countries with as many as 50,000 people dying daily as consequence of infection ${ }^{14,16}$. Plant remedies are increasingly being recognized by scientists as a very important lowcost alternative to industrially-produced antibiotics which are not available to all who need them because their high price ${ }^{5,25}$. Publishing findings on the antimicrobial activity of plant remedies is important because it raises awareness of alternative medicines which in turn drives biotechnology development.

The guava tree, Psidium guajava Linnaeus, is distributed from México down to São Paulo State, Brazil, being indigenous to Central América and part of South America between Colombia and Peru? Worldwide literature information is available about the antimicrobial activity by $P$. guajava on different members of such bacterial families as Enterobacteriaceae, Vibrionaceae, Micrococcaceae and Propionibacteriaceae $e^{6,18,20,25}$.

The objective of this study was to evaluate the antimicrobial effects of guava tree leaf extracts on diarrhea-causing bacteria. Screening was 


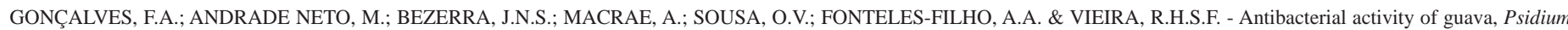
guajava Linnaeus, leaf extracts on diarrhea-causing enteric bacteria isolated from Seabob shrimp. Xiphopenaeus kroyeri (Heller). Rev. Inst. Med. trop. S. Paulo, 50(1): 11-15, 2008.

carried out on Staphylococcus aureus, Salmonella spp. and Escherichia coli strains isolated from seabob shrimp as well as on laboratory culture strains to evaluate whether differences between laboratory and environmental strains existed.

\section{MATERIALS AND METHODS}

1. Shrimp sampling: Approximately $3.5 \mathrm{~kg}$ of seabob shrimp were bought from the Mucuripe Fishmarket (Fortaleza, Ceará, Brazil) and were transported on ice to the laboratory. The shrimp were ground using a porcelain mortar and pestle. From this material, 25 g were separated for the isolation of Salmonella spp. A further $25 \mathrm{~g}$ was homogenized with $225 \mathrm{~mL}$ of an $0.85 \%$ saline solution for the isolation of other bacterial species.

2. Isolation of Staphyloccocus aureus, Salmonella spp. and Escherichia coli: S. aureus and Salmonella spp. were isolated using the protocols described in the Compendium of Methods for the Microbiological Examination of Foods ${ }^{8}$ and $E$. coli using the multiple tube-fermentation technique described by MEHLMAN et al. (1984) ${ }^{17}$.

3. Obtaining plant extracts: Guava leaves were collected from urban orchards at Fortaleza and registered at the Herbarium of the Department of Biological Science, Federal University of Ceará (registry no. 30387), having been identified by the botanical officer E. Nunes, on March 3, 2001. Afterwards, they were dried at room temperature. $100 \mathrm{~g}$ of leaf material were mechanically ground and wrapped in filter paper and fractions thereof were extracted using a Soxhlet extractor and solvents in the following order of polarity: hexane, ethyl acetate and methanol. The extracted solutions were concentrated in a rotary evaporator (R-114, Büchi, Switzerland) resulting in $1.87 \mathrm{~g}$ of viscous material from the hexane extraction and $2.95 \mathrm{~g}$ from the ethyl acetate extraction. This material was suspended in 20 and $30 \mathrm{~mL}$ of hexane and ethyl acetate respectively. Both extracts were brown in color. Viscous extract weighing $7.75 \mathrm{~g}$ was recovered using methanol and suspended in $80 \mathrm{~mL}$ of the same solvent. Extracts were stored in a refrigerator at $5{ }^{\circ} \mathrm{C}$ until used.

4. Obtaining the essential oil: The essential oil was obtained from fresh leaves of $P$. guajava using a Clevenger type doser and the extraction methodology of GOTTLIEB \& MAGALHÃES $(1960)^{11} .840$ $\mathrm{g}$ of fresh leaves were submerged in $2.5 \mathrm{~L}$ of distilled water in a $5 \mathrm{~L}$ glass bowl and submitted to the hydro-distillation technique for 24 hours. The water and oil mixture were separated by drying with anhydrous sodium sulphate $\left(\mathrm{Na}_{2} \mathrm{SO}_{4}\right)$ and then filtered, resulting in a final volume of $1.4 \mathrm{~mL}$ of essential oil. The essential oil was stored in a refrigerator prior to further investigation.

5. Antimicrobial activity: The antimicrobial activity of the extracts and the essential oil was evaluated by the disc diffusion method described by BAUER et al. (1966) ${ }^{3}$ with modifications. The bacterial strains isolated from the seabob shrimp were $S$. aureus, Salmonella spp. and E. coli. The experimental controls were type strains of $E$. coli (ATCC 25922), S. aureus (IOC 3089) and Salmonella Anatum (IOC 4279-99). Test colonies were taken from a 24-hour culture, grown on slanted TSA agar and suspended in sterile saline solution (0.85\%). Optical density was compared with a 0.5 tube on the McFarland scale $\left(10^{8} \mathrm{UFC} / \mathrm{mL}\right)^{12}$. With the aid of a moist sterile swab the suspensions were spread on plates of Mueller Hinton (MH) Difco agar, left to get dry for about 15 minutes and incubated at $37^{\circ} \mathrm{C}$.

Filter paper discs (0.25, Schleicher \& Schuell), which had previously been sterilized in an oven at $100{ }^{\circ} \mathrm{C}$ for two hours, were soaked with the three extracts at four concentrations (5, 10, 15 and 20 $\mu \mathrm{L})$. Discs were placed on $\mathrm{MH}$ agar and inoculated with the test bacteria and incubated at $37^{\circ} \mathrm{C}$ for $18-24$ hours.

After incubation, inhibition haloes were measured to determine which concentrations of the extracts inhibited bacterial growth. The resulting haloes were compared with control discs, soaked in hexane, ethyl acetate and methanol solvents without plant extract. Control discs were not used in the tests with essential oil because no solvents were used with this treatment.

A parallel analysis with commercial antimicrobial agents was conducted in order to compare their antimicrobial efficiency with the plant extracts and essential oil. The same method of spreading a bacterial suspension on $\mathrm{MH}$ agar in Petri dishes was used. The sensibiodisc kit (CECON) was used for the comparison ${ }^{3}$. The antibiotics used for comparison with $S$. aureus were: Ampicillin-AMP (10 mcg), Cephalothin-KF (30 mcg), Chloramphenicol-CL (30 mcg), Erythromycin-EM (15 mcg), Lincomycin-LIN (2 mcg), and Vancomycin-VAN (30 mcg). The Enterobacteriaceae family isolates, E. coli $^{24}$ and Salmonella spp. ${ }^{26}$ were tested against: Cefotaxime-CT (30 mcg), Cefoxitin-FX (30 mcg), Chloramphenicol-CL (30 mcg), Gentamicin-GEN (10 mcg) and Tetracycline-TC (30 mcg). All assays were made in triplicates and each experiment was repeated four times. The haloes of commercial discs were measured according to guidelines set up by the Sensibiodisc-CECON Manual whereby each strain was defined as sensitive, intermediate or resistant to the tested commercial antimicrobial substances.

6. Statistical Analysis: Analysis of the antibacterial action of the extracts of guava leaves was carried out at different concentrations, by comparing the mean diameter of the inhibition haloes as a variable. When the halo produced surpassed the measurement of the diameter of the disc $(6.00-\mathrm{mm})$ we considered that there had been growth inhibition of the tested strains. The one-way Analysis of Variance was used to test the effect of the $484.30 \mu \mathrm{g} / \mathrm{disc}(5 \mu \mathrm{L}), 968.70 \mu \mathrm{g} / \mathrm{disc}$ $(10 \mu \mathrm{L}), 1453.10 \mu \mathrm{g} /$ disc $(15 \mu \mathrm{L})$ and $1937.50 \mu \mathrm{g} /$ disc $(20 \mu \mathrm{L})$ concentrations of the methanol extract of guava leaves. The estimated means were compared two by two using the Tukey test, with a 5\% significance level.

\section{RESULTS}

Table 1 shows the concentrations of the extracts of guava leaves which were tested against strains of Staphylococcus aureus, Salmonella and Escherichia coli isolated from seabob shrimp. The inhibition haloes seen surrounding discs soaked in the extracts varied from $7.00 \mathrm{~mm}$ to $11.25 \mathrm{~mm}$ with all the bacteria being sensitive to at least one of the extracts. The methanol extract inhibited bacterial growth more than hexane and ethyl acetate. The solvents, without plant extract, were used as negative controls and did not inhibit bacterial growth.

The effect of guava leaf extracts was greater on $S$. aureus than on 
E. coli and Salmonella spp. Based on statistical analyses, the antimicrobial action of the methanol extract for concentrations 484.30 $\mu \mathrm{g} /$ disc and 1,453.10 $\mu \mathrm{g} /$ disc (Table 1 ) did not differ significantly for any of the strains tested. For concentration $968.70 \mu \mathrm{g} / \mathrm{disc}$, the diameter of the inhibition halo for the Salmonella spp. differed from that for $E$. coli, whereas for concentration 1,937.50 $\mu \mathrm{g} / \mathrm{disc}$, the inhibition of Salmonella spp. was significantly different from the others.

In Table 1, we note that the guava leaf essential oil inhibited the growth of $S$. aureus more than the methanol, hexane and ethyl acetate extracts. This antibiotic action was also observed for the type strain of Salmonella Anatum, but not observed with E. coli. Almost all of the commercial antibiotics evaluated in these experiments were shown to efficiently inhibit $S$. aureus. Strains isolated from shrimp proved to be resistant to a number of commercial antibiotics (Table 2).

The $S$. aureus type strain was shown to be sensitive to erythromycin, chloramphenicol, lincomycin and vancomycin. Resistance to ampicillin and intermediary resistance to cephalotin were observed. In the tests carried out with antibiotics, the Salmonella spp. strains isolated from shrimp proved to be resistant to tetracycline, but sensitive to chloramphenicol, cefotaxime, cefoxitin and gentamicin. The type strain behaved but similarly demonstrating intermediate resistance to tetracycline (Table 2).

The E. coli strain isolated from seabob shrimp was resistant to

Table 1

Antimicrobial activity of guava leaf (Psidium guajava L.) essential oils and methanol, hexane, ethyl acetate extracts on S. aureus, E.coli and Salmonella Anatum, type strains, and isolates from seabob shrimp (Xiphopenaeus kroyeri)

\begin{tabular}{|c|c|c|c|c|c|c|c|c|c|c|c|c|c|}
\hline \multirow[t]{3}{*}{ Microorganisms } & \multirow[t]{3}{*}{ Essential oil } & \multicolumn{12}{|c|}{ Extracts ( $\mu \mathrm{g} /$ disc) } \\
\hline & & \multicolumn{4}{|c|}{ Hexane } & \multicolumn{4}{|c|}{ Ethyl acetate } & \multicolumn{4}{|c|}{ Methanol } \\
\hline & & 467.5 & 935.0 & 1402.5 & 1870.0 & 491.6 & 983.3 & 1474.5 & 1966.6 & 484.3 & 968.7 & 1453.1 & 1937.5 \\
\hline Shrimp isolates & & \multicolumn{12}{|c|}{ Halo (mm) } \\
\hline S. aureus & 18 & 8.75 & 8.0 & 8.25 & 7.0 & 7.25 & 7.50 & na & na & 8.50 & 9.25 & 8.25 & 8.25 \\
\hline E. coli & na & 7.0 & 7.0 & 7.0 & 7.0 & 7.0 & 7.0 & 7.0 & 7.0 & 8.0 & 8.0 & 9.0 & 8.25 \\
\hline Salmonella spp. & na & na & na & na & na & na & na & na & na & 8.75 & 9.75 & 9.5 & 11.25 \\
\hline \multicolumn{14}{|l|}{ Type strains } \\
\hline S. aureus & 11 & 7.0 & 7.0 & 7.0 & 7.0 & 8.0 & 8.0 & 8.0 & 8.0 & 8.25 & 7.75 & 8.25 & 9.0 \\
\hline E. coli & na & 7.0 & 7.0 & 7.0 & 7.0 & na & na & na & na & 9.0 & 8.0 & 8.5 & 8.0 \\
\hline Salmonella Anatum & 18 & na & na & na & na & na & na & na & na & 8.25 & na & na & na \\
\hline
\end{tabular}

na - no activity.

Table 2

The susceptibility of S. aureus, E.coli and Salmonella spp. laboratory type strains and isolates from Seabob shrimp (Xiphopenaeus kroyeri) to commercial antimicrobial agents

\begin{tabular}{|c|c|c|c|c|c|c|c|c|}
\hline \multirow{3}{*}{ Antimicrobials } & \multicolumn{8}{|c|}{ Staphylococcus aureus } \\
\hline & \multicolumn{4}{|c|}{ Shrimp isolate } & \multicolumn{4}{|c|}{ Type strain } \\
\hline & \multicolumn{2}{|c|}{ Susceptibility } & \multicolumn{2}{|c|}{ Halo(mm) } & \multicolumn{2}{|c|}{ Susceptibility } & \multicolumn{2}{|c|}{ Halo(mm) } \\
\hline Ampicillin (AMP) & \multicolumn{2}{|c|}{$\mathrm{R}$} & \multicolumn{2}{|c|}{15.0} & \multicolumn{2}{|c|}{$\mathrm{R}$} & \multicolumn{2}{|c|}{14.0} \\
\hline Cephalotin (KF) & \multicolumn{2}{|c|}{ S } & \multicolumn{2}{|c|}{25.0} & \multicolumn{2}{|c|}{ I } & \multicolumn{2}{|c|}{15.0} \\
\hline Chloramphenicol (CL) & \multicolumn{2}{|c|}{ S } & \multicolumn{2}{|c|}{25.0} & \multicolumn{2}{|c|}{ S } & \multicolumn{2}{|c|}{30.0} \\
\hline Erythromycin (EM) & \multicolumn{2}{|c|}{ S } & \multicolumn{2}{|c|}{23.0} & \multicolumn{2}{|c|}{$\mathrm{S}$} & \multicolumn{2}{|c|}{30.0} \\
\hline Lincomycin (LIN) & \multicolumn{2}{|c|}{ S } & \multicolumn{2}{|c|}{25.0} & \multicolumn{2}{|c|}{$\mathrm{S}$} & \multicolumn{2}{|c|}{25.0} \\
\hline Vancomycin (VAN) & \multicolumn{2}{|c|}{ S } & \multicolumn{2}{|c|}{18.0} & \multicolumn{2}{|c|}{$\mathrm{S}$} & \multicolumn{2}{|c|}{17.0} \\
\hline \multirow[t]{3}{*}{ Antimicrobials } & \multicolumn{4}{|c|}{ Salmonella spp. and $S$. Anatum } & \multicolumn{4}{|c|}{ E. coli } \\
\hline & \multicolumn{2}{|c|}{ Shrimp isolate } & & train & & solate & & train \\
\hline & Sus. & Halo(mm) & Sus. & Halo(mm) & Sus. & Halo(mm) & Sus. & Halo(mm) \\
\hline Cefotaxime (CT) & S & 30.0 & S & 30.0 & I & 30.0 & $\mathrm{R}$ & 30.0 \\
\hline Cefoxitin (FX) & S & 21.0 & $\mathrm{~S}$ & 21.0 & $\mathrm{R}$ & 11.0 & $\mathrm{R}$ & 11.0 \\
\hline Chloramphenicol (CL) & S & 22.0 & $\mathrm{~S}$ & 28.0 & $\mathrm{R}$ & 12.0 & $\mathrm{R}$ & 11.0 \\
\hline Gentamicin (GEN) & S & 22.0 & S & 23.0 & S & 21.0 & $\mathrm{~S}$ & 21.0 \\
\hline Tetracycline (TC) & $\mathrm{R}$ & 11.0 & I & 18.0 & S & 20.0 & I & 17.0 \\
\hline
\end{tabular}

$\mathrm{R}$ - resistant, $\mathrm{S}$ - susceptible, I - intermediate. 


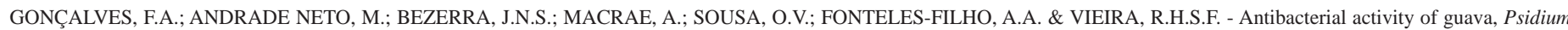
guajava Linnaeus, leaf extracts on diarrhea-causing enteric bacteria isolated from Seabob shrimp. Xiphopenaeus kroyeri (Heller). Rev. Inst. Med. trop. S. Paulo, 50(1): 11-15, 2008.

cefoxitin and chloramphenicol and was sensitive to tetracycline and gentamicin (Table 2). E. coli strain also presented intermediary resistance to cefotaxime. Gentamicin had the greatest inhibitory effect of the antibiotics against the laboratory strain of $E$. coli. Resistance to cefoxitin, chloramphenicol, cefotaxime was also observed for $E$. coli type strain along with intermediary resistance to tetracycline.

\section{DISCUSSION}

Our results support the findings of RABE \& VAN STADEN $(1997)^{19}$, where greater overall antimicrobial activity was seen with a methanol extract than with the essential oil and other extracts. While it is a common practice in traditional medicine to use plant extracts prepared with water, as is the case with infusions, decoctions and plasters, it seems unlikely that the active compounds present in water extracts are the same as those responsible for the action in the methanol extracts. The chemistry involved in chewing, boiling, soaking, rubbing and extracting plant medicines is complex. The results in Table 1 suggest that there are multiple and different anti-microbial agents present in each type of extract acting in different ways on different bacterial strains. VIEIRA et al. (2001) $)^{25}$ have also reported the antibacterial effect of guava leaves extracts and found that they inhibited the growth of the $S$. aureus. GNAN \& DEMELLO (1999) ${ }^{10}$ testing guava leaf extract found good antimicrobial activity against nine different strains of Staphylococcus aureus. In contrast to the results reported here, JAIARJ et al. (1999) ${ }^{15}$, testing for antibacterial action of aqueous, methanol and chloroform extracts of $P$. guajava, on strains of $S$. aureus isolated from clinical patients, obtained better results from aqueous extracts than from methanol extract. BERDY et al. $(1982)^{4}$ and CACERES et al. (1993) ${ }^{5}$ described the antibiotic activity of the aqueous extract of dried leaves of Psidium guajava to two compounds, namely guajaverin and psidiolic acid. Data on Table 1 both support and contradict previous findings concerning which type of plant extraction method results in greatest microbial inhibition. Such variability is perhaps explained in the light of multiple different active agents and different bacterial species. The secondary metabolism of plants is complex and results in an incredible variety of metabolic products. SANCHES et al. (2005) $)^{21}$ evaluated the antibacterial activities of Psidium guajava against Gram positive and negative bacteria testing ethanol: water extract of $P$. guajava leaves, stem bark and root, and aqueous extract against Staphylococcus aureus were found to be more active by using ethanol:water extract than with just aqueous extract. High variability is not unexpected and serves to highlight gaps in our understanding of plant medicines, and provides questions and direction for further research. When comparing these data with others, what really matters is the powerful inhibitory effect of guava leaves on many common diseases causing enteric pathogens.

While the overall inhibitory effect of the essential oils in this experiment was less than for methanol, its individual effect on $S$. aureus was greater. According to ROBBERS et al. (1997) ${ }^{20}$, a higher concentration of active chemical compounds in essential oils explain their stronger inhibitory action (JAIARJ et al. (1999) ${ }^{15}$; ANDRADENETO et al. (1994) ${ }^{1}$. Within the genus Psidium, essential oil constituents are principally comprised of monoterpenes, 1.8-cineol, $\rho$-cimen and acetate of $\alpha$-terpenil. The complex composition of essential oils offers a variety of pharmacological resources and great potential for the development of novel drugs.
Investigating the antimicrobial effect of guava leaves involved a comparison of their effect (Table 1) with commercially developed antibiotics (Table 2) by comparing the inhibition haloes in those tables. We note that the commercial antibiotics had a larger inhibitory effect than the guava leaf extractions. This is not surprising and reinforces the position that commercially perfected and tested antibiotics should be used in treatments whenever available. Table 2 also provides data which support the findings of SILVA \& HOFER (1995) ${ }^{22}$ about E. coli isolated from marine fish, where multiresistance to commercial antibiotic was reported. Multidrug resistance is defined as resistance to at least two different classes of antibiotics ${ }^{9}$. An increase in the occurrence of bacterial strains resistant to more than one commercial antibiotic isolated from natural environments is cause for concern. Increased resistance has typically been ascribed to the indiscriminate use of drugs with antibiotic properties on human beings, livestock protection and food production, resulting in the development of resistant strains $^{23}$. Our data demonstrate that multiple resistance is frequently found in strains from environmental samples where this type of exposure seems unlikely. In developing countries, especially in rural, coastal and estuarine environments, where child diarrhea is common and life-threatening, special attention is required when preparing fish for consumption. In conclusion, guava leaf extracts and essential oil are very active against $S$. aureus, thus making up important potential sources of new antimicrobial compounds.

\section{RESUMO}

\section{Avaliação da atividade antibacteriana de extrato de folhas de goiabeira, Psidium guajava Linnaeus, sobre bactérias entéricas diarreiogênicas, isoladas de camarão sete-barbas, Xiphopenaeus kroyeri (Heller)}

O chá de folhas de goiaba Psidium guajava Linnaeus é comumente usado como remédio nas gastrenterites e diarréias infantis por aqueles que não têm acesso a antibióticos. Esta pesquisa estudou o efeito antibacteriano sobre bactérias causadoras de diarréias, do óleo essencial e do extrato de folhas de goiabeira usando como diluente: metanol, hexano e acetato de etila. Os extratos foram testados sobre Staphylococcus aureus, Salmonella spp. e Escherichia coli. As bactérias testadas foram isoladas de camarão sete-barbas Xiphopenaeus kroyeri (Heller) usando-se como controle cepas padrão, de cada espécie. Das bactérias testadas, o melhor efeito inibitório foi observado sobre Staphylococcus aureus. O extrato de metanol apresentou maior inibição bacteriana. O óleo essencial mostrou ação inibitória contra $S$. aureus e Salmonella spp. Foi demonstrada alguma resistência das cepas isoladas de camarão aos antibióticos comerciais testados. Estes dados confirmam que remédios à base de folhas de goiabeira podem ser utilizados em casos de diarréia provocada por essas bactérias, quando o uso de antibiótico for restrito. Conclui-se que extratos de folhas de goiaba e o seu óleo essencial são muito ativos contra $S$. aureus, tornando-os importantes fontes em potencial de novos compostos antimicrobianos.

\section{REFERENCES}

1. ANDRADE-NETO, M.; ALENCAR, J.W.; SILVEIRA, E.R. \& CUNHA, A.N. - Volatile constituents of Psidium pohlianum Berg. and Psidium guyanensis Pers. J. Essential Oils Res., 6: 299-300, 1994. 


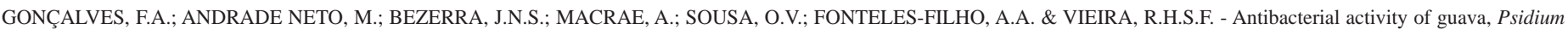
guajava Linnaeus, leaf extracts on diarrhea-causing enteric bacteria isolated from Seabob shrimp. Xiphopenaeus kroyeri (Heller). Rev. Inst. Med. trop. S. Paulo, 50(1): 11-15, 2008.

2. ARIDOGAN, B.C.; BAYDAR, H.; KAYA, S. et al - Antimicrobial activity and chemical composition of some essential oils. Arch. pharm. Res., 25: 860-864, 2002.

3. BAUER, A.W.; KIRBY, W.M.M.; SHERRIS, J.C. \& TURCK, M. - Antibiotic susceptibility testing by a standardized single disk method. Amer. J. clin. Path., 36: 493-496, 1966.

4. BERDY, J.; ASZLOS, A.; BOSTIAN, M. \& MCNITT, K.L. - Hand book of antibiotic compounds. Boca Raton, CRC Press, 1982. v. 8 , part 1, p. 410 and part 2, p. 429.

5. CÁCERES, A.; FLETES, L.; AGUILAR, L. et al. - Plants used in Guatemala for the treatment of gastrointestinal disorders. Confirmation of activity against enterobacteria of 16 plants. J. Ethnopharmacol., 38: 31-38, 1993.

6. CHOMNAWANG, M.T.; SURASSMO, S.; NUKOOLKARN, V.S. \& GRITSANAPAN, W. - Antimicrobial effects of Thai medicinal plants against acne-inducing bacteria. J. Ethnopharmacol., 101: 330-333, 2005.

7. CORREA, M.P. - Dicionário de plantas úteis do Brasil. Brasília, Ministério da Agricultura, Instituto Brasileiro de Desenvolvimento Florestal (IBDF), 1984.

8. DOWNES, F.P. \& ITO, K.P. - Compendium of methods for the microbiological examination of foods. 4 ed. Washington, APHA, 2001.

9. GIBBS, S.G.; GREEN, C.F.; TARWATER, P.M. et al. - Isolation of antibiotic-resistant bacteria from the air plume downwind of a swine confined or concentrated animal feeding operation. Environ. Hlth perspect., 114: 1032-1037, 2006.

10. GNAN, S.O. \& DEMELLO, M.T. - Inhibition of Staphylococcus aureus by aqueous goiaba extracts. J. Ethnopharmacol., 68: 103-108, 1999.

11. GotTlieB, O.R. \& MAGalHÃes, M.T. - Modified distillation trap. Chem. Anal., 49: 114,1960

12. HINDLER, A.J. \& JORGENSEN, J.H.B. - Procedures in antimicrobial susceptibility testing. In: MAHON, C.R. \& MANUSELIS Jr., G. Textbook of diagnostic Microbiology. Philadelphia, W.B. Saunders, 1995. p. 63-64.

13. HOFFMANN, F.L.; CRUZ, C.H.G.; VINTURIM, T.M. \& FAZIO, M.L.S - Levantamento da qualidade higiênico-sanitária de pescado comercializado na cidade de São José do Rio Preto (SP). Rev. Hig. alimentar, 13: 45-49, 1999.

14. HUEBNER, R.R.E.; WASAS, A.; MUSHI, A. et al. - Nasopharyngeal carriage and antimicrobial resistence in isolates of Streptococcus pneumoniae and Heamophilus influenzae Type b in children under 5 years of age in Bostswana. Int. J. infect. Dis., 3: 18-25, 1998.
15. JAIARJ, P.; KHOOHASWAN, P.; WONGKRAJANG,Y. et al. - Anticough and antimicrobial activities of Psidium guajava Linn. leaf extract. J. Ethnopharmacol., 67: 203-212, 1999.

16. LUTTERODT, G.D. - Inhibition of Microlax-induced experimental diarrhoea with narcotic-like extracts of Psidium guajava leaf in rats. J. Ethnopharmacol., 37: 151157, 1992.

17. MEHLMAN, I.J.; ANDREWS, W.H. \& WENTZ, B.A. - Coliform Bacteria. In ASSOCIATION OF OFFICIAL ANALYTICAL CHEMISTS/AOAC. Bacteriological analytical manual. 6. ed. Arlington, Food and Drug AdministrationFDA, 1984. p. 5.01-5.07.

18. QADAN, F.; THEWAINI, A.J.; ALI, D.A. et al. - The antimicrobial activities of Psidium guajava and Juglans regia leaf extracts to acne-developing organisms. Amer. J. clin. Med., 33: 197-205, 2005

19. RABE, T. \& VAN STADEN, J. - Antibacterial activity of South African plants used for medicinal purposes. J. Ethnopharmacol., 56: 81-87,1997.

20. ROBBERS, J.E.; SPEEDIE, M.K. \& TYLER, V.E. - Farmacognosia e farmacobiotecnologia. São Paulo, Premier, 1997. p. 372.

21. SANCHES, N.R.; CORTEZ, D.A.G.; SCHIAVINI, M.S. et al. - An evaluation of antibacterial activities of Psidium guajava (L.). Braz. Arch. Biol. Technol., 48: 429436, 2005.

22. SILVA, A.A.L. \& HOFER, E. - Escherichia coli from salt-water fish: resistance to drugs and colicinogeny. Biom. Lett., 51: 175-181, 1995

23. SOLARI, C.A.; REIS, E.F.M.; DIAS, J.A.R. \& HOFER, E. - Resistência antimicrobiana de Salmonella Agona oriundas de várias regiões do Brasil. Mem. Inst. Oswaldo Cruz, 81: 7-14, 1986.

24. VIEIRA, R.H.S.F.; EVANGELISTA, N.S.S. \& RODRIGUES, D.P. - Colimetria das águas marinhas de Fortaleza (Ceará, Brasil) e detecção de cepas de Escherichia col enteroinvasora (EIEC) e enteropatogênica clássica (EPEC). Arq. Cienc. Mar, 30: 27-31, 1996.

25. VIEIRA, R.H.S.F.; RODRIGUES, D.P.; GONÇALVES, F.A. et al. - Microbicidal effect of medicinal plant extracts (Psidium guajava Linn. and Carica papaya Linn.) upon bacteria isolated from fish muscle and known to induce diarrhea in children. Rev. Inst. Med. trop. S. Paulo, 43: 145-148, 2001.

26. YILDIRMAK, T.; YAZGAN, A. \& OZCENGIZ, G. - Multiple drug resistance patterns and plasmid profiles of non-typhi Salmonella in Turkey. Epidemiol. Infect., 121: 303-307,1998.

Received: 22 May 2007

Accepted: 9 November 2007 